\title{
MARINE RAM-TYPE STEERING GEAR DETAILS LOAD TRANSFER FEATURES
}

\section{ОСОБЛИВОСТІ ПЕРЕДАВАННЯ НАВАНТАЖЕННЯ ДЕТАЛЯМИ СУДНОВОЇ РУЛЬОВОЇ МАШИНИ ПЛУНЖЕРНОГО ТИПУ}

\author{
V.O. Protsenko, professor, D.Sc., V.O. Nastasenko, professor, D.Sc., \\ M.V. Babiy, associate professor, Ph.D., A.O. Bilokon, engineer \\ В.О. Проценко, професор, д.т.н., В.О. Настасенко, професор, д.т.н., \\ М.В. Бабій, доцент, к.т.н., А.О. Білоконь, інженер \\ Kherson State Maritime Academy, Ukraine \\ Херсонська державна морська академія, Україна
}

\begin{abstract}
The article deals with steering gears, used on marine and river ships, namely with ram-type steering gears. Article topicality due to the fact that ship controllability and sailing safety depends of steering gears reliability. Reliability could be increased through the refinement of processes, which took place during the perception and transfer of load.

Process of lateral force perception by plungers and guide beams is studied theoretically. It is shown that perception depends of gap size between plunger and sleeve and could pass in one, two or three stages. Those stages are characterized changing in the loading process plungers fixing conditions, and respectively plunger lateral load proposed to determinate by three design schemes.

Received expressions for calculation ultimate gaps of "plunger-sleeve» pare landing, that gives the limits of application each of three design schemes. Ratios for determination load of plunger and guide beam are received trough consideration their joint deformation for each design schemes. On the example of YOOWON-MITSUBISHI YDFT-335-2 ram-type steering gear is shown that in new gear, where landing gap is minimal and conditioned by tolerances of plunger and sleeve diameters, guide beam can take only 2.0...6.5\% of lateral force, which applied to it and plunger from tiller. In steering gear with partially worn out plunger and sleeve in time of rudder feather shifting from diametric plane to board (when $\alpha=5 \ldots 35^{\circ}$ ), guide beam could take $4.7 \ldots 6.8 \%$ of lateral force. The source of origin significant loads on plungers in ram-type steering gears is application of sinus-type mechanism for transformation progressive plunger motion to rotating tiller motion. Decreasing lateral loads on plunger through using unloading guide beams, with considering low unloading percent is ineffective. Guide beams availability complicates steering gear construction, increasing number of friction surfaces and trough this complicates steering gear maintenance.
\end{abstract}

Keywords: steering ram-type gear, plunger, guide beam, tiller, torque, lateral force, load, distribution, deformation, landing gap.

Постановка проблеми в загальному вигляді та її зв'язок із важливими науковими чи практичними завданнями.

Гідравлічні рульові машини (ГРМ) є одними з найбільш відповідальних елементів судна, оскільки вони, разом з головним двигуном, забезпечують його кероване переміщення. Від безвідмовності рульових машин напряму залежать керованість судна та безпека мореплавства [1]. Підвищення безвідмовності може бути забезпечено, в тому числі, за рахунок уточнення процесів, що проходять при сприйнятті та передачі машинами навантаження, процесів виникнення мінімально неминучих незворотних втрат енергії [2], механізмів втрати працездатності. 
Аналіз останніх досліджень і публікацій, в яких започатковано розв'язання даної проблеми і виділення невирішених раніше частин загальної проблеми.

ГРМ 3 плунжерним приводом набули широкого розповсюдження завдяки своїм перевагам у порівнянні з машинами, що мають поршневий чи лопатевий привід, основною серед яких $\epsilon$ висока навантажувальна здатність. Тривала експлуатація плунжерних ГРМ супроводжується і їх дослідженнями, які, проте, стосуються в основному удосконалення керування [3], дослідження автоколивних процесів [4], удосконалення гідросистеми [5], елементів приводу насосів [6], важільних систем [7]. В той же час, відомі розрахункові моделі силової взаємодії та передавання навантаження деталями плунжерних ГРМ дещо ідеалізовані. Зокрема відзначено [8], що одним із основних недоліків таких машин є низький механічний ККД, але при виведенні виразу для обчислення втрат на тертя при роботі машини вважається, що поперечне навантаження, яке діє на плунжер з боку румпеля повністю сприймається напрямною балкою, і відповідно тертя розвивається виключно в стику плунжера з цією балкою. Крім невідповідності виразу для ККД і фізичних явищ, що виникають у ГРМ при роботі, наведене припущення виключає розроблення точної розрахункової моделі міцності як плунжера так i напрямної, формування точного представлення про механізм тертя і зношування плунжерних втулок.

\section{Формулювання мети роботи.}

Викладені факти обумовлюють мету даної роботи - вивчити процес сприйняття поперечного навантаження від румпеля плунжером та напрямною балкою у ГРМ плунжерного типу. Для досягнення поставленої мети необхідно вирішити наступні завдання:

- описати основні етапи процесу сприйняття плунжером та напрямною поперечного навантаження з урахуванням величини зазору в парі «плунжер-втулка»;

- отримати вирази для математичного опису границь цих етапів та обчислення основних параметрів кожного етапу;

- оцінити ефективність роботи напрямних за рахунок обчислення долі поперечного навантаження, яке здатна сприйняти напрямна на прикладі конструкції експлуатованої ГРМ плунжерного типу;

- зробити висновки та запропонувати напрямки подальших досліджень.

\section{Виклад матеріалу дослідження 3 повним обгрунтуванням отриманих наукових результатів.}

Плунжер і напрямна при дії на них поперечного навантаження утворюють статично невизначену систему, розподіл навантаження між стрижнями якої належить вивчити. Для цього на початковому етапі встановимо початкові припущення за умови виконання яких розв'язуватимемо поставлені завдання:

- деформування плунжерів та напрямних відбувається в межах границі пружності їх матеріалів;

- плунжер і напрямна мають незмінний по довжині момент інерції перерізу;

- контактними деформаціями в місцях контакту плунжера з втулкою та напрямною можна знехтувати (розрахунок показує, що урахування контактної піддатливості дозволяє підвищити точність розрахунків менше ніж на 0,5\%);

- зазор у стику опори плунжера і напрямної (точка $B$, рис. 2) відсутній;

- напрямна закріплена на рамі машини жорстко обома кінцями і умови закріплення іiі кінців протягом навантаження незмінні.

На першому етапі опишемо механізм сприйняття навантаження плунжерами та напрямними в залежності від величини зазору посадки плунжера у втулці. Плунжер зазвичай сполучений з циліндровою втулкою по посадці із зазором $2 Z\left(2 Z_{\min } \leq 2 Z \leq 2 Z_{\text {max }}\right)$, найчастіше H9/g9, чи H9/g7, в експлуатації допускається граничне збільшення цього зазору до величини $2 Z_{\text {lim }}=(0,0020 \ldots 0,0025) d_{p}$ [9]. Таке спряження втулки та плунжера допускає поворот останнього при його деформації на кут $\theta_{\max }=2 Z / l_{s}\left(l_{s}-\right.$ довжина плунжерної втулки (рис. 1$\left.)\right)$. 


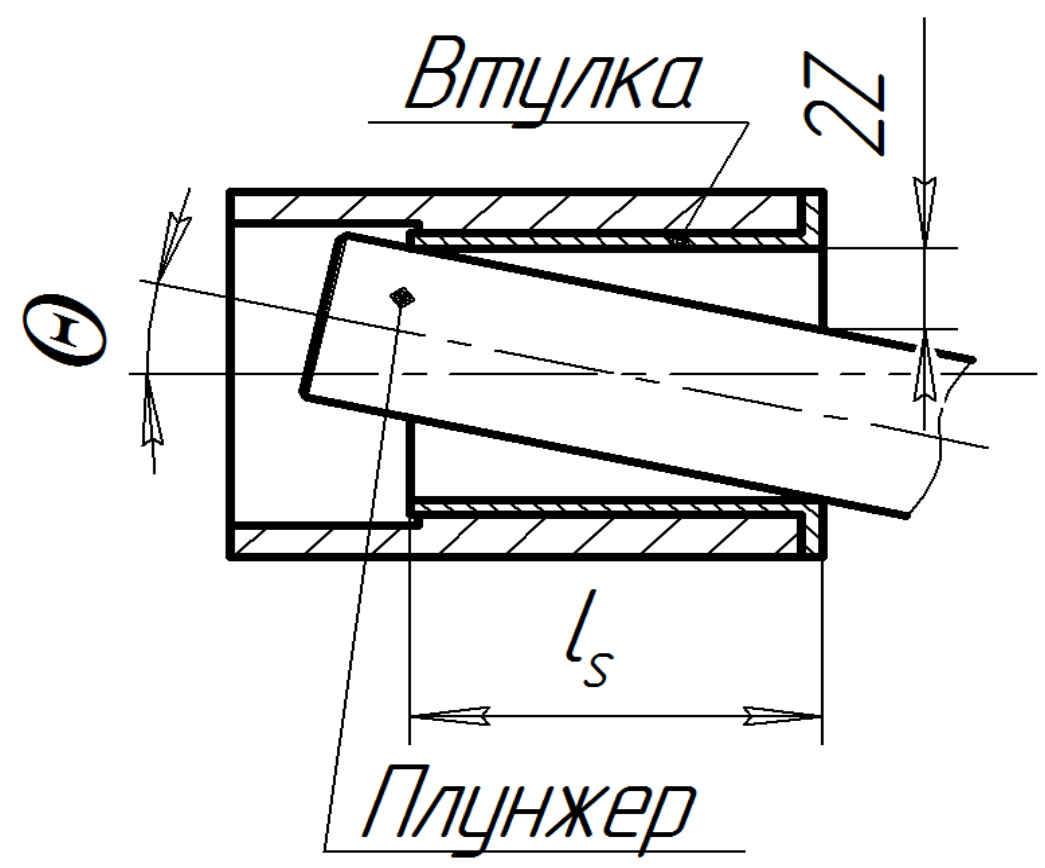

Рис. 1. Схема до визначення кута повороту плунжера

Розглянемо процес передачі поперечного навантаження $F_{l}$ від румпеля на плунжер і напрямну. Якщо зазор $2 Z$ близький до $2 Z_{\min }$, то сприйняття долі поперечного навантаження плунжером i, відтак, його деформування, може проходити за нижчеописаною схемою $I$ в три стадії (рис. 2):

a) до тих пір, поки кут повороту плунжера в опорі $A$ не перевищить $\theta_{\max }\left(\theta_{A 1}<\theta_{\max }\right)$, його можна вважати балкою на шарнірних опорах $A$ та $E$, що згинається силою $F_{p 1}$ із утворенням деформації $\delta_{p 1}$ в місці прикладення сили, та поворотом плунжера в опорі $E$ на величину $\theta_{E 1}$;

б) після закриття зазора в опорі $A\left(\theta_{A 1}=\theta_{\max }\right)$ і до закриття зазору в опорі $E\left(\theta_{E 1}+\theta_{E 2}<\right.$ $\left.\theta_{\max }\right)$ плунжер можна вважати балкою 3 однією жорсткою $(A)$, а іншою шарнірною $(E)$ опорою, яка в цьому випадку сприйматиме зусилля $F_{p 1}+F_{p 2}$ із виникненням відповідної деформацієї $\delta_{p 2}$;

в) після закриття зазора в опорі $E\left(\theta_{E 1}+\theta_{E 2}=\theta_{\max }\right)$ плунжер являтиме собою балку 3 обома жорсткими опорами, яка сприйматиме повне зусилля $F_{p}=F_{p 1}+F_{p 2}+F_{p 3}$, що призведе до виникнення деформації $\delta_{p 3}$;

Напрямна протягом всіх трьох описаних стадій буде балкою з обома защемленими кінцями, що деформуватиметься зусиллям $F_{g}$ сумісно $з$ плунжером, зазнавши при цьому деформації $\delta_{g}$.

Сума зусиль, що їх сприймають плунжер та напрямна, $\epsilon$ поперечною силою $F_{l}$, яка діє на плунжер з боку повзуна та румпеля і викликана гідродинамічним моментом на стерні, що його через румпель та балер повертає машина. Умова сумісності деформування плунжера та напрямної записується у вигляді рівності їх деформацій, що в результаті дає систему (0), яка для описаної тристадійної схеми $(n=3)$ набуде вигляду $(1)$.

$$
\begin{gathered}
\left\{\begin{array}{l}
F_{l}=\sum_{i=1}^{n} F_{p i}+F_{g} ; \\
\sum_{i=1}^{n} \delta_{p i}=\delta_{g} .
\end{array}\right. \\
\left\{\begin{array}{l}
F_{l}=F_{p 1}+F_{p 2}+F_{p 3}+F_{g} ; \\
\delta_{p 1}+\delta_{p 2}+\delta_{p 3}=\delta_{g} .
\end{array}\right.
\end{gathered}
$$




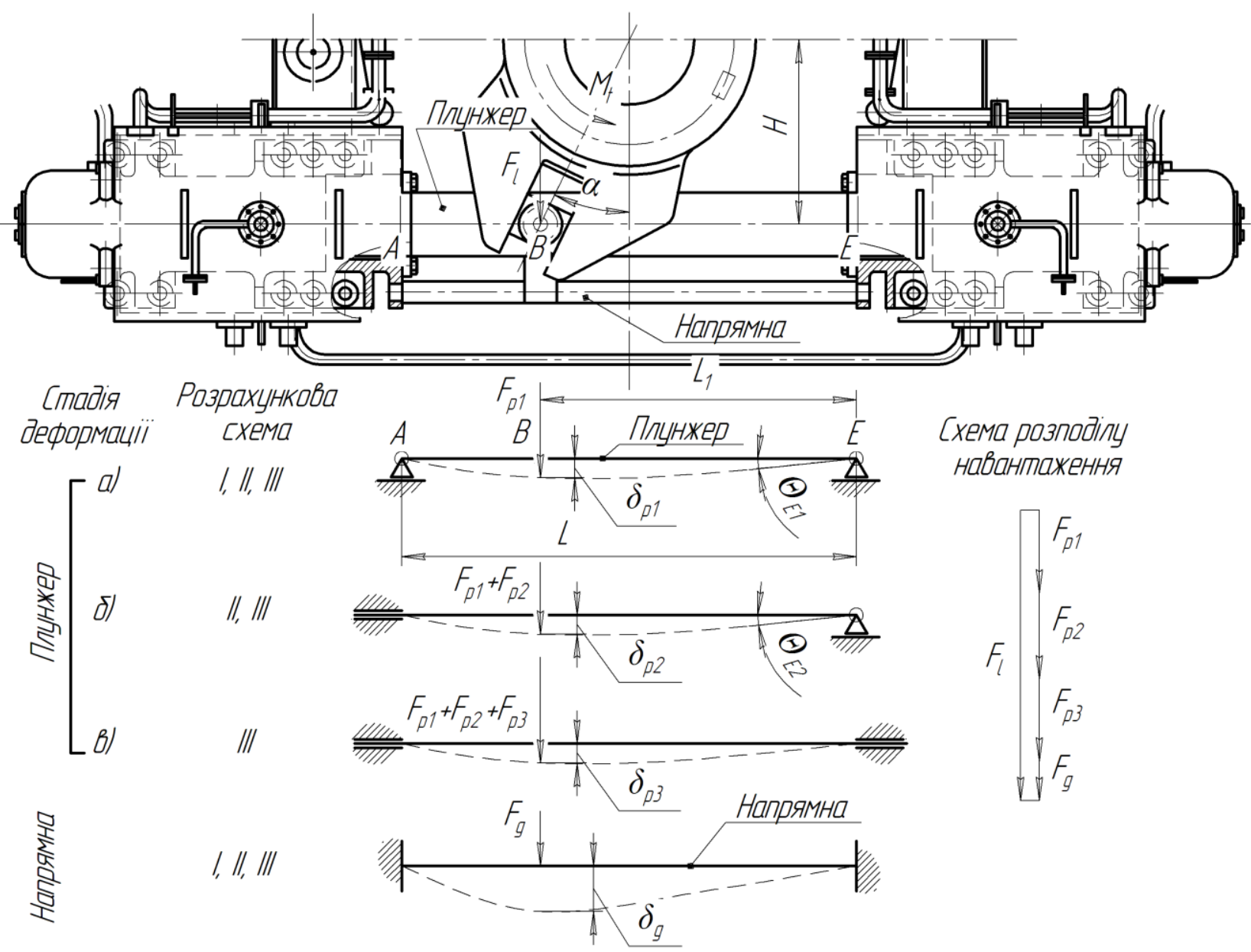

Рис. 2. Розрахункова схема плунжера та напрямної на різних стадіях деформації плунжера

Деформації плунжера та напрямної за прийнятої розрахункової схеми запишуться наступним чином [10...14]

$$
\begin{gathered}
\delta_{p 1}=F_{p 1} \frac{\left(L-L_{1}\right)^{2} L_{1}^{2}}{3 E J_{p} L}=F_{p 1} \lambda_{p 1} ; \\
\delta_{p 2}=\left(F_{p 1}+F_{p 2}\right) \frac{\left(L-L_{1}\right)^{3} L_{1}^{2}\left[3\left(L-L_{1}\right)+4 L_{1}\right]}{12 E J_{p} L^{3}}=\left(F_{p 1}+F_{p 2}\right) \lambda_{p 2} ; \\
\delta_{p 3}=\left(F_{p 1}+F_{p 2}+F_{p 3}\right) \frac{\left(L-L_{1}\right)^{3} L_{1}^{3}}{3 E J_{p} L^{3}}=\left(F_{p 1}+F_{p 2}+F_{p 3}\right) \lambda_{p 3} ; \\
\delta_{g}=F_{g} \frac{\left(L-L_{1}\right)^{3} L_{1}^{3}}{3 E J_{g} L^{3}}=F_{g} \lambda_{g},
\end{gathered}
$$

де $E$ - модуль пружності матеріалу плунжера та напрямної;

$J_{p}$ та $J_{g}$ - моменти інерції поперечного перерізу плунжера та напрямної відповідно;

$\lambda_{p 1}, \lambda_{p 2}, \lambda_{p 3}$ та $\lambda_{g}-$ лінійні піддатливості плунжера (на кожній стадії деформування) та напрямної відповідно.

Кути повороту кінців плунжера в опорах $A$ та $E$ при цьому становитимуть:

$$
\begin{gathered}
\theta_{A 1}=F_{p 1} \frac{L^{2}}{6 E J_{p}}\left(\frac{L_{1}}{L}-\left(\frac{L_{1}}{L}\right)^{3}\right)=F_{p 1} \gamma_{p A 1} \\
\theta_{E 1}=F_{p 1} \frac{L^{2}}{6 E J_{p}}\left(\frac{L-L_{1}}{L}-\left(\frac{L-L_{1}}{L}\right)^{3}\right)=F_{p 1} \gamma_{p E 1}
\end{gathered}
$$




$$
\theta_{E 2}=\left(F_{p 1}+F_{p 2}\right) \frac{L^{2}}{6 E J_{p}}\left(\left(\frac{L-L_{1}}{L}\right)^{2}-\left(\frac{L-L_{1}}{L}\right)^{3}\right)=\left(F_{p 1}+F_{p 2}\right) \gamma_{p E 2} ;
$$

де $\gamma_{p A 1}, \gamma_{p E 1}$ та $\gamma_{p E 2}$ - кутові піддатливості плунжера віднесені до опор $A$ та $E$ на відповідних стадіях сприйняття навантаження.

Умови першого $\left(\theta_{A 1}=\theta_{\max }\right)$ і другого $\left(\theta_{E 2}=\theta_{\max }-\theta_{E 1}\right)$ етапів деформування та наведені співвідношення (6)...(8) дають можливість отримати вирази для відповідних зусиль:

$$
\begin{gathered}
F_{p 1}=\frac{6 E J_{p} \theta_{A 1}}{L^{2}\left(\frac{L_{1}}{L}-\left(\frac{L_{1}}{L}\right)^{3}\right)}=\frac{2 Z}{l_{s}} \chi_{p A 1} ; \\
F_{p 1}+F_{p 2}=\frac{4 E J_{p}\left(\theta_{\max }-\theta_{E 1}\right)}{L^{2}\left(\left(\frac{L-L_{1}}{L}\right)^{2}-\left(\frac{L-L_{1}}{L}\right)^{3}\right)}=\left[\frac{2 Z}{l_{s}}-F_{p 1} \gamma_{p E 1}\right] \chi_{p E 2}=\frac{2 Z}{l_{s}}\left[1-\chi_{p A 1} \gamma_{p E 1}\right] \chi_{p E 2},
\end{gathered}
$$

де $\chi_{A 1}$ та $\chi_{E 2}$ - кутові жорсткості плунжера, віднесені до опор $A$ та $E$ на відповідних стадіях сприйняття навантаження;

Розв'язання системи (1) із використанням співвідношень (2)...(5), (9), (10) дає можливість отримати вираз для обчислення складової $F_{p 3}$

$$
F_{p 3}=\frac{F_{l} \lambda_{g}-F_{p 1} \lambda_{p 1}-\left[F_{p 1}+F_{p 2}\right]\left(\lambda_{p 2}+\lambda_{p 3}+\lambda_{g}\right)}{\lambda_{p 3}+\lambda_{g}} .
$$

Описана тристадійна модель перестане працювати при зменшенні зусилля $F_{p 3}$ до нуля. 3 огляду на це, прирівнюючи вираз (11) до нуля, з використанням (9) та (10), отримаємо нове співвідношення (12) для визначення максимального зазора $2 Z_{1}$, до досягнення якого працюватиме описана тристадійна схема $I$ (загалом інтервал її роботи $2 Z_{\min } \ldots 2 Z_{1}$ ):

$$
2 Z_{1}=\frac{F_{l} \lambda_{g} l_{s}}{\chi_{p A 1} \lambda_{p 1}+\chi_{p E 2}\left[1-\chi_{p A 1} \gamma_{p E 1}\right]\left(\lambda_{p 2}+\lambda_{p 3}+\lambda_{g}\right)} .
$$

Якщо зазор посадки плунжера збільшиться понад величину $2 Z_{l}$, тристадійна схема $I$ перетвориться в двостадійну $(n=2)$ схему $I I$ (міститиме тільки етапи а) та б)) (рис. 2), за рахунок виключення етапу в) деформування плунжера як балки з обома жорсткими опорами. Для неї система (0) набуде вигляду (13), і справедливими будуть вирази (2), (3), (5)...(8).

$$
\left\{\begin{array}{l}
F_{l}=F_{p 1}+F_{p 2}+F_{g} \\
\delta_{p 1}+\delta_{p 2}=\delta_{g}
\end{array}\right.
$$

За рахунок розв'язання системи (13), отримаємо вираз для обчислення зусилля $F_{p 2}$

$$
F_{p 2}=\frac{F_{l} \lambda_{g}-F_{p 1}\left(\lambda_{p 1}+\lambda_{p 2}+\lambda_{g}\right)}{\lambda_{p 2}+\lambda_{g}}
$$

3 умови припинення сприйняття плунжером з жорстко опертим кінцем $A$ і шарнірно опертим кінцем $E$ всього навантаження $\left(F_{p 2}=0\right)$, отримаємо верхнє значення $2 Z_{2}$ зазора в парі «плунжер-втулка» для інтервалу $2 Z_{1} \ldots 2 Z_{2}$ роботи двостадійної схеми $I I$ :

$$
2 Z_{2}=\frac{F_{l} \lambda_{g} l_{s}}{\chi_{p A 1}\left(\lambda_{p 1}+\lambda_{p 2}+\lambda_{g}\right)} .
$$

Якщо зазор в опорі $A$ буде достатнім для безперешкодного повороту плунжера через деформацію від дії поперечної сили $\left(\theta_{A}<\theta_{\max }, 2 Z \geq 2 Z_{2}\right)$, то попередня схема $I I$ спроститься до одностадійної (схема $I I I$ з одним етапом а)), де плунжер сприймає зусилля $F_{p}$, як балка на обох шарнірних опорах $(n=1)$ (рис. 2). Для цього випадку можна записати систему (16), розв'язання якої з використанням (9) дає вираз (17) для поперечного навантаження плунжера.

$$
\left\{\begin{array}{l}
F_{l}=F_{p 1}+F_{g} \\
\delta_{p 1}=\delta_{g}
\end{array}\right.
$$




$$
F_{p 1}=\frac{F_{l}}{1+\lambda_{p 1} / \lambda_{g}} .
$$

Табличя 1 - Характеристика розрахункових схем плунжера та напрямної

\begin{tabular}{|c|c|c|c|c|c|c|c|c|}
\hline \multirow[t]{2}{*}{$\begin{array}{l}\text { № } \\
\text { iнт. }\end{array}$} & \multirow{2}{*}{$\begin{array}{c}\text { Зазор } \\
\text { посадки } 2 Z\end{array}$} & \multirow{2}{*}{$\begin{array}{l}\text { Розрахункова } \\
\text { схема }\end{array}$} & \multirow{2}{*}{$\begin{array}{c}\text { Кількість } \\
\text { стадій } \\
\text { (етапів) } \\
\text { деформації } \\
\text { плунжера } n\end{array}$} & \multicolumn{4}{|c|}{$\begin{array}{l}\text { Навантаження плунжера } \\
\text { (вирази для обчислення) }\end{array}$} & \multirow{2}{*}{$\begin{array}{c}\text { Навантаження } \\
\text { напрямної } F_{g}\end{array}$} \\
\hline & & & & $F_{p 1}$ & $F_{p 2}$ & $F_{p 3}$ & $F_{p}$ & \\
\hline 1 & $2 Z_{\min } \ldots 2 Z_{1}$ & I & 3 & (9) & (10) & $(11)$ & \multirow{3}{*}{$\sum_{i=1}^{n} F_{p i}$} & \multirow{3}{*}{$F_{l}-F_{p}$} \\
\hline 2 & $2 Z_{1} \ldots 2 Z_{2}$ & II & 2 & (9) & (10) & - & & \\
\hline 3 & $>2 Z_{2}$ & III & 1 & (9) & - & - & & \\
\hline
\end{tabular}

Кількісний аналіз розподілу поперечного навантаження між плунжером та напрямною виконаємо на прикладі рульової машини YOOWON-MITSUBISHI YDFT-335-2 фірми Mitsubishi Heavy Industries, що розвиває максимальний момент на балері 3432 кН·м. Ії основні геометричні параметри наступні: діаметр плунжера та його втулок $d_{p}=300$ мм (посадка $\mathrm{H} 9 / \mathrm{g} 9,2 Z_{\min }=0,056$ мм, $2 Z_{\max }=0,316$ мм), довжина плунжерної втулки $l_{s}=300$ мм, напрямна циліндрична, іiї діаметр $d_{g}=100$ мм, відстань між циліндрами $L=2100$ мм, між осями плунжерів $2 H=1700$ мм. Плунжер та напрямна сталеві, $E=2,1 \times 10^{5}$ МПа. Відстань $L_{l}$ до точки $B$ прикладення поперечної сили (рис. 3) при цьому обчислюється за виразом (18), а поперечне зусилля, яке сприймають плунжер і напрямна за виразом (19) [8], момент інерції перерізу плунжера та втулки обчислюватимемо як $J_{i} \approx 0,05 d^{4}[15]$.

$$
\begin{gathered}
L_{1}=0,5 L+H \operatorname{tg} \alpha ; \\
F_{l}=F_{t} \sin \alpha=\frac{M_{t}}{2 H} \sin \alpha,
\end{gathered}
$$

де $\alpha$ - кут повороту румпеля;

$M_{t}$ - момент на румпелі.

Роботу машини-прототипа розглядатимемо у припущенні іiі встановлення на контейнеровозі місткістю 2842 TEU $(D W T=39374 \mathrm{~T}, L=222 \mathrm{M}, B=30 \mathrm{M}, V=22,6$ вуз), для якого було обчислено $[1,12]$ момент на румпелі (рис. 4) при кутах перекладки стерна $0 . . .35^{\circ}$.

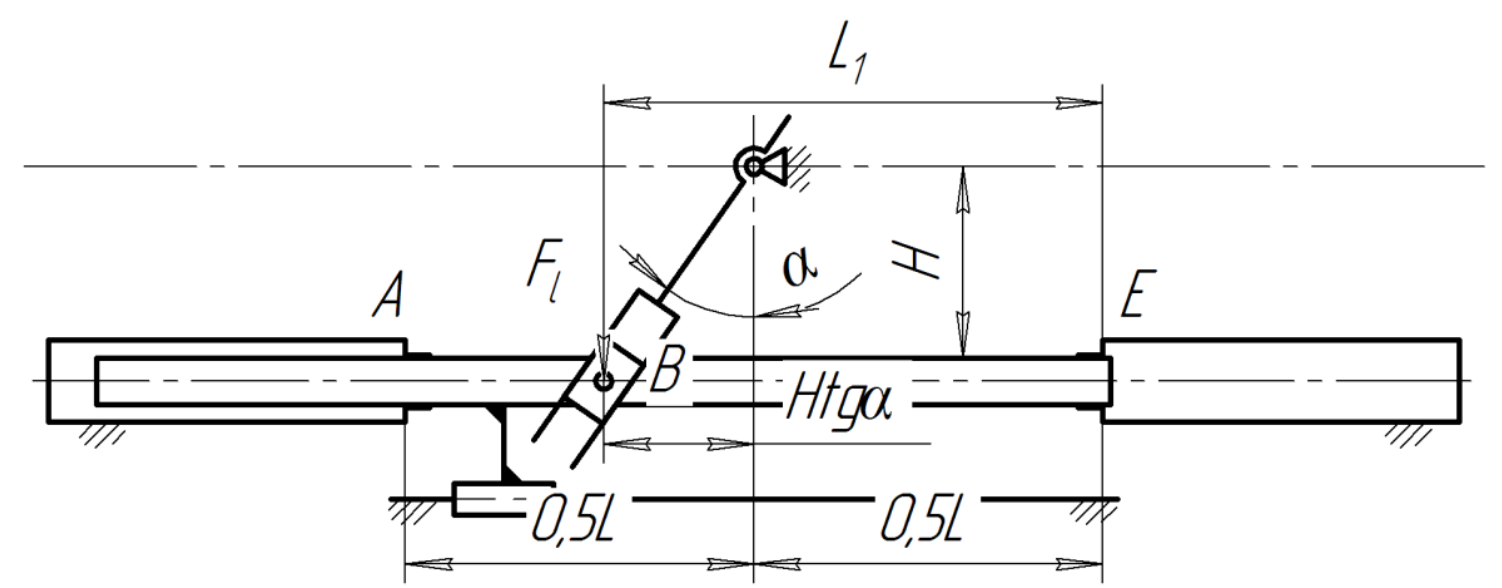

Рис. 3. Схема до розрахунку положення точки прикладення розпірного зусилля 


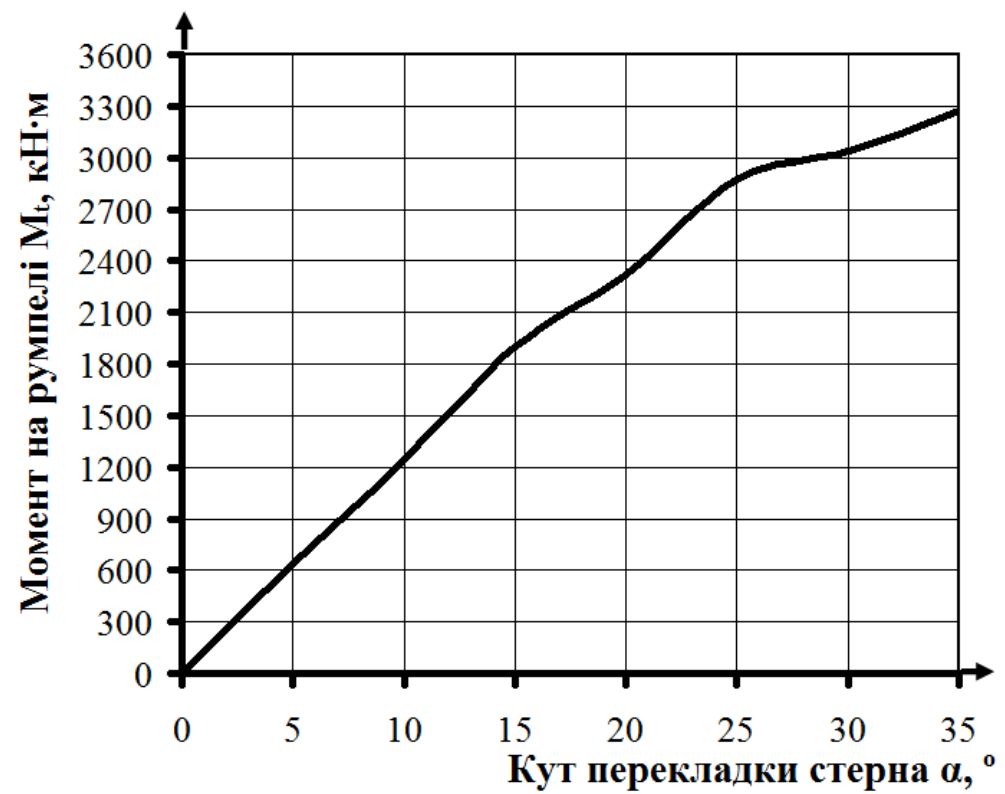

Рис. 4. Графік залежності моменту на румпелі від кута перекладки стерна

Згідно графіка, максимальний момент машина повинна розвивати в положенні стерна $\alpha=35^{\circ}\left(M_{t}=3273\right.$ кН·м), а його напрямок додатний, що забезпечує дію бічної сили від осі балера, робота плунжерів при цьому відбувається на «розштовхування» (в бік збільшення за рахунок деформації вигину відстані $H$ ) i, відповідно передачу навантаження від плунжерів на напрямні. Для цього випадку за наведеними виразами (12) та (15) обчислено, що характерні зазори описаних етапів сприйняття навантаження плунжером становитимуть $2 Z_{1}=0,380$ мм, $2 Z_{2}=0,652 \mathrm{мм}, 2 Z_{\text {lim }}=0,750$ мм. Ефективність роботи напрямної по розвантаженню плунжера оцінюватимемо за рахунок обчислення коефіцієнта завантаження напрямної $K_{g l}=$ $F_{g} / F_{l}$. Результати розрахунків представлені на рис. 5 , рис. 6 , рис. 9, рис. 10 вони відповідають наведеним інтервалам (табл. 1) зазора $2 Z$ посадки пари «плунжер-втулка». Рис. 7 та рис. 8 містять залежність зусиль, що сприймає плунжер на кожному з етапів сприйняття ним навантаження від зазора посадки. Аналізуючи рис. 5, можна стверджувати, що нова машина, яка має зазор посадки $2 Z_{\min }<2 Z<2 Z_{\max }(0,056$ мм $<2 Z<0,316$ мм) буде працювати в межах розрахункової схеми $I$ за тристадійним варіантом сприйняття навантаження плунжером, оскільки $2 Z_{\max }<2 Z_{1}(0,316$ мм $<0,380$ мм), при цьому в аналізованому положенні стерна $\left(\alpha=35^{\circ}\right)$ напрямна сприйматиме лише $2,0 \ldots 6,5 \%$ поперечного зусилля, що діятиме на плунжер з боку румпеля.

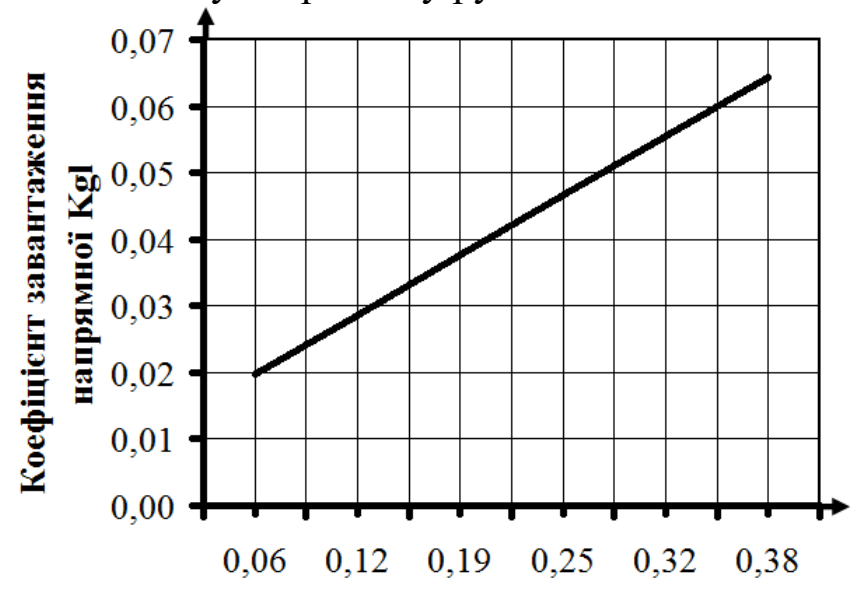

Зазор посадки 2Z, мм

Рис. 5. Залежність коефіиієнта завантаження напрямної в першому інтервалі зазору посадки «плунжер-втулка»

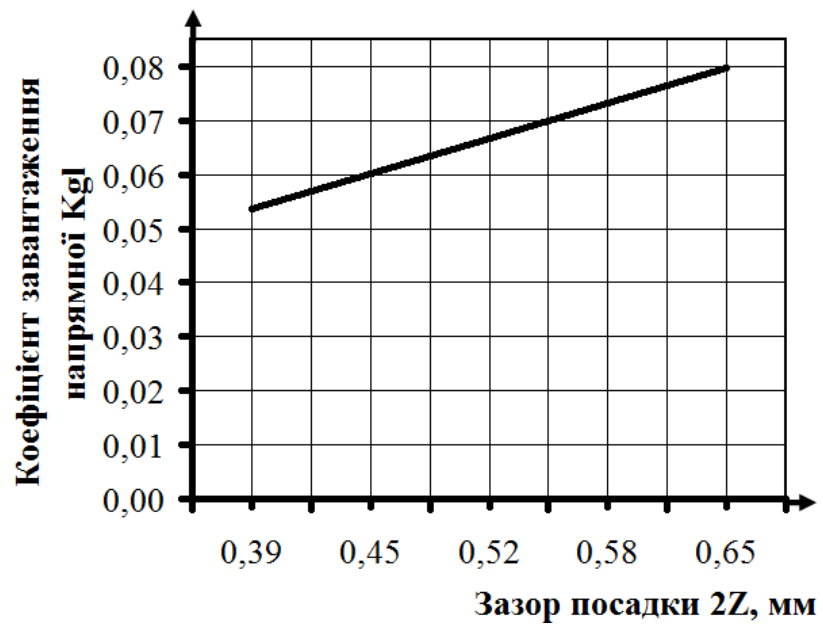

Рис. 6. Залежність коефіцієнта завантаження напрямної в другому інтервалі зазору посадки «плунжер-втулка» 


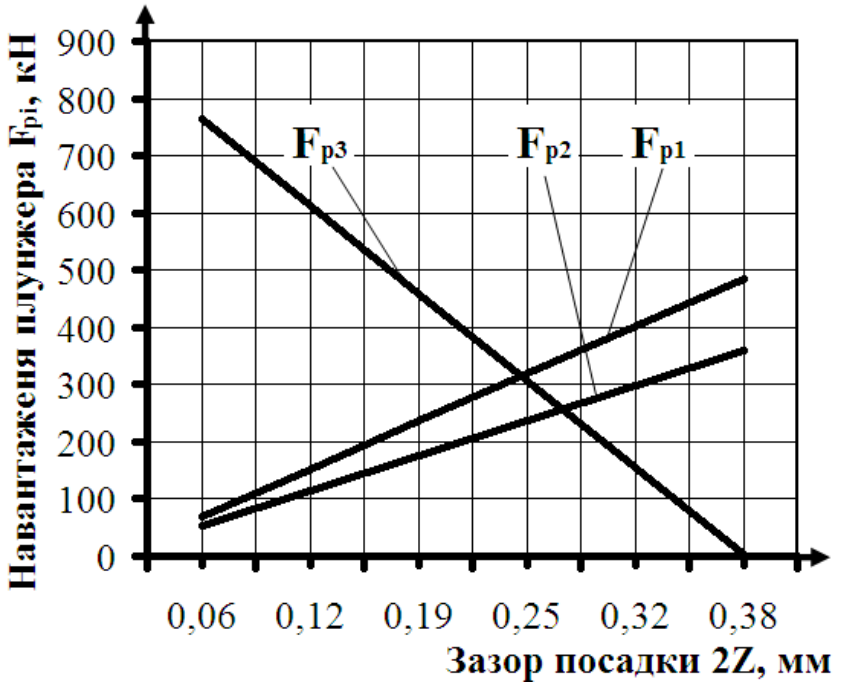

Рис. 7. Залежність навантаження плунжера в першому інтервалі зазору посадки

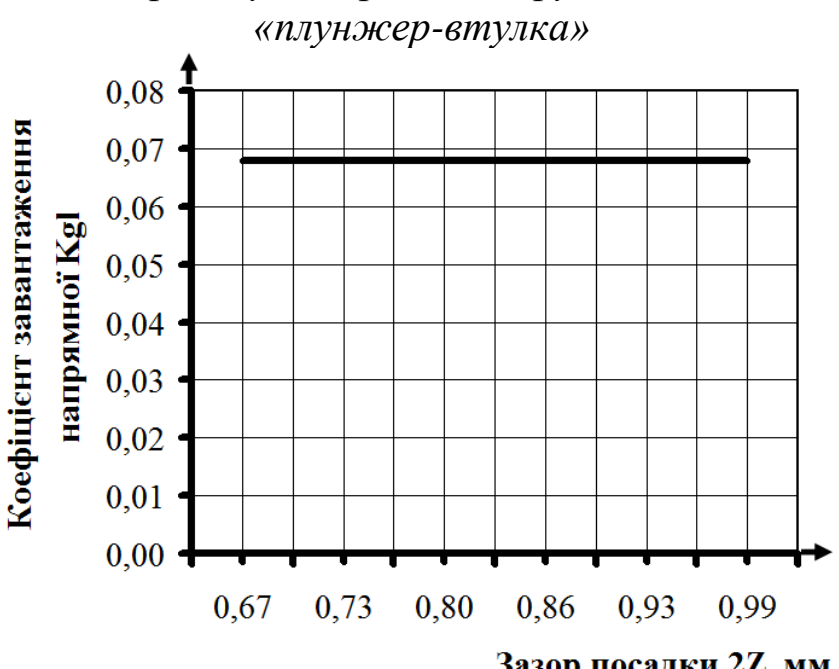

Рис. 9. Залежність коефіиієнта завантаження напрямної в третьому інтервалі зазору посадки «плунжер-втулка»

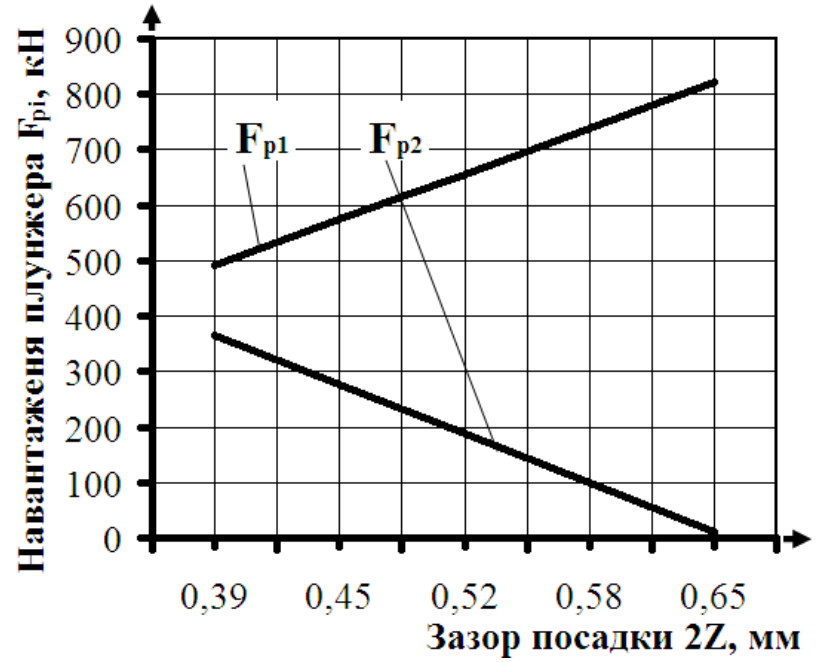

Рис. 8. Залежність коефіиієнта завантаження напрямної в другому інтервалі зазору посадки «плунжер-втулка»

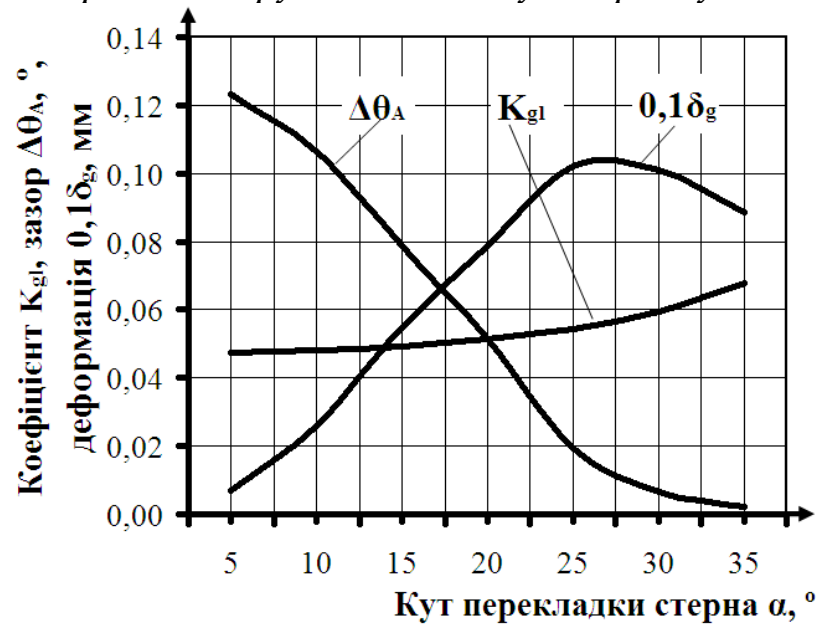

Рис. 10. Залежність коефіиієнта завантаження напрямної, кутового зазору в опорі А та прогину напрямної від кута перекладки стерна

При зносі втулки до величини зазору $2 Z_{2}=0,652$ мм, доля навантаження, що сприйматиметься напрямною може збільшитись до $8,0 \%$ (рис. 6). При роботі машини за наявності зазорів понад $2 Z_{2}$, напрямна сприйматиме $6,8 \%$ поперечного навантаження (рис. 9).

Рис. 10 демонструє залежність коефіцієнта $K_{g l}$ від кута повороту стерна $\alpha$ за умови, що зазор посадки плунжера у втулці становить $0,90 \times 2 Z_{\text {lim }}=0,675$ мм, що відповідає експлуатації рульової машини 3 частково зношеними втулками. Аналіз цього графіка говорить про те, що протягом перекладки стерна $з$ діаметральної площини на борт напрямна сприймає лише 4,7...6,8\% поперечного навантаження. На цьому-ж графіку подано залежність зміни кутового зазора в опорі $A\left(\Delta \theta_{A}=\theta_{\max }-\theta_{A 1}\right)$, що доводить коректність застосування розрахункової схеми III при побудові даного графіка, оскільки цей зазор більший за нуль при всіх $\alpha$. Графік також свідчить, що максимальний прогин напрямної (та плунжера), $\delta_{g}=1,02$ мм, матиме місце при куті перекладки стерна $\alpha=25^{\circ}$, при $\alpha=35^{\circ}$ він зменшуматиметься до $\delta_{g}$ $=0,88 \mathrm{MM}$.

При зміні знаку моменту на румпелі на протилежний, наприклад через особливості гідромеханіки стерна, плунжери будуть працювати на «зтягування» (в бік зменшення відстані $H$ ), і навантаження в розглянутій машині YDFT-335-2 на напрямні передаватись не буде взагалі $\left(K_{g l}=0\right)$, що пояснюється відсутністю кінематичного замикання між плунжером та напрямною (хоча в деяких конструкціях ГРМ таке замикання передбачене). 


\section{Висновки і перспектива подальшої роботи по даному напрямку}

В роботі теоретично досліджено процес сприйняття поперечного навантаження плунжером та напрямною суднової гідравлічної рульової машини плунжерного типу 3 урахуванням зазорів у парі «плунжер-втулка», при цьому:

- показано, що в залежності від величини зазору в парі «плунжер-втулка» сприйняття плунжером поперечного навантаження може проходити в один, два, або три етапи, що характеризуються зміною в процесі деформування умов закріплення кінців плунжера як двохопорної балки, відповідно навантаження плунжера запропоновано визначати за трьома розрахунковими схемами;

- отримані вирази для обчислення граничних зазорів посадки «плунжер-втулка», що дає можливість визначати межі застосування кожної з трьох розрахункових схем. За рахунок розгляду процесу сумісного деформування плунжера та напрямної отримані співвідношення для розрахунку навантаження плунжера для кожного розрахункового випадку;

- застосуванням отриманих результатів до машини YOOWON-MITSUBISHI YDFT-335-2, показано, що в новій ГРМ, де зазор посадки обумовлений допусками спряжених поверхонь власне плунжера та втулки, напрямна може сприймати лише $2,0 \ldots 6,5 \%$ бічного навантаження, що прикладається до неї та плунжера з боку румпеля при перекладці стерна. У машині 3 частково зношеними плунжерними втулками, за час перекладки стерна 3 діаметральної площини на борт (при $\alpha=5 \ldots 35^{\circ}$ ), напрямна може сприймати 4,7 ..6,8\% поперечного навантаження;

- джерелом виникнення значних поперечних навантажень на плунжери у ГРМ плунжерного типу є застосування важільного механізму синусного типу, а зменшення цих зусиль шляхом застосування розвантажувальних напрямних, з огляду на низький відсоток навантаження, який вони знімають з плунжерів, $є$ малоефективним. Наявність напрямних ускладнює конструкцію ГРМ, збільшує їі масу, додає поверхонь тертя, а відтак ускладнює технічне обслуговування.

Напрямки подальших досліджень:

- вивчення розподілу навантаження між плунжером та напрямною з урахуванням зазорів між плунжером і напрямною;

- аналіз можливості підвищення ефективності сприйняття напрямною поперечного навантаження;

- уточнення енергетичних втрат у ГРМ з урахуванням розподілу навантаження між плунжером і напрямною та пошук напрямків підвищення енергетичної ефективності;

- дослідження структури важільного механізму ГРМ і пошук напрямків зниження кількості надлишкових зв'язків.

\section{ЛІТЕРАТУРА}

1. Харин В.М. Судовые гидравлические рулевые машины / В.М. Харин. - О.: Фенікс, 2005. $-280 \mathrm{c}$.

2. Сагін С.В. Теорія і практика енергоперетворення на суднах з мінімально неминучими незворотними втратами: дис. ... д-ра техн. наук: спец. 05.22.20 - експлуатація та ремонт засобів транспорту; Національний університет "Одеська морська академія". - Одеса, 2019. - 402 c.

3. Гончаренко А.В. Експлуатація активних транспортних систем в умовах багатоальтернативності та невизначеності: дис. ... д-ра техн. наук: спец. 05.22.20 експлуатація та ремонт засобів транспорту; Національний авіаційний університет. - К., 2016. -328 c.

4. Булюкина Н.А. Фрикционные автоколебания в судовых гидравлических рулевых машинах: автореф. дис. канд. техн. наук: спец. 05.08 .05 - судовые энергетические 
установки и их элементы (главные и вспомогательные); ФГБОУ ВПО «СанктПетербургский государственные морской технический университет».-СПб., 2013.-23c.

5. Месропян А.В. Методика идентификации струйно-золотниковой гидравлической рулевой машины / А.В. Месропян, К.А. Широкова, В.А. Целищев // Вестник УГАТУ. Серия «Машиностроение. Гидравлические машины, гидропневмоагрегаты». - Уфа: УГАТУ. - 2007. - Т.9, №6(24). - С. $44-55$.

6. Проценко В.О. Експертиза відмови муфти насосного агрегату суднової гідравлічної рульової машини / В.О. Проценко // Науковий вісник Херсонської державної морської академії. - Херсон: ХДМА. - 2013. - № 1(8) - С. 179 - 184.

7. Овчарук О.М. Обгрунтування параметрів приводу суднової рульової машини 3 важільною редукцією / О.М. Овчарук, В.О. Проценко // Науковий вісник Херсонської державної морської академії. - Херсон: ХДМА. - 2014. - № 2(11) - С. 185 - 196.

8. Завиша В.В. Судовые вспомогательные механизмы и системы / В.В. Завиша, Б.Г. Декин. - М.: Транспорт, $1984-357$ с.

9. Ремонт судовых гидравлических систем / В.И. Маркитантов, П.М. Милованцев, М.Я. Морозов. - М.: Транспорт, 1989. - 174 с.

10. Справочник по сопротивлению материалов / Г.С. Писаренко, А.П. Яковлев, В.В. Матвеев - К.: Наукова думка, 1988. - 736 с.

11. Фесик С.П. Справочник по сопротивлению материалов / С.П. Фесик. - К.: Будівельник, $1982-280 \mathrm{c}$.

12. Шваб'юк В.І. Опір матеріалів / В.І. Шваб'юк. - К.: Знання, 2016. - 407 с.

13. Опір матеріалів / Гурняк Л.І., Гуцуляк Ю.В., Юзьків Т.Б. - Львів: «Новий світ - 2000», 2019. - 363 c.

14. Посацький С.Л. Опір матеріалів / С.Л. Посацький. - Львів: Видавництво Львівського університету, 1963. - 360 с.

15. Прикладна механіка / Д.М. Коновалюк, Р.М. Ковальчук, О.О. Фесенко, В.І. Шваб'юк, М.П. Ярошевич. - Луцьк: ЛДТУ, 2003. - 776 с. 